\title{
Guidelines regarding thefts in libraries
}

\author{
A draft
}

by The Security Committee of ACRL's Rare Books and Manuscript Section

\section{Section I. Preventing Library Theft}

\section{A. Appoint a Library Security Officer (LSO)}

The LSO should be given authority by the library and the parent institution to act on their behalf while working with the institution's legal counsel and security force. Consult Section II of the "ACRL Guidelines for the Security of Rare Books, Manuscripts, and Other Special Collections" for a fuller description of the LSO's role, available from the ACRL office and published in CERL News 60,9 (1999); see also the RBMS Web site/Guidelines.

\section{B. Form a Security Planning Group}

A Security Planning Group, made up of the LSO and other appropriate personnel, will be responsible for developing a security plan to prevent theft and a detailed plan of action to follow when a theft is discovered. The plan may be a part of the institution's disaster plan or constitute a separate plan. The plans should not be public documents (e.g., they should not be posted on a Web site), but accessible only to appropriate library and institutional personnel.

\section{Communicate with the public relations department}

Establish a working relationship with the institution's public relations office so that timely and accurate announcements can be made to the press when a theft is discovered.

\section{Communicate with law enforcement agencies}

Establish contact and foster good working relations with law enforcement agencies - institutional, local, state, and/or federal-and determine which of them has original jurisdiction over the library (e.g., campus security, local or state police, etc.) and under which circumstances they should be called. The library should maintain a list of contacts in each level of law enforcement and discuss the plan of action with each. (See Appendix I for "Networking Resources Directory for Protection and Recovery.") The FBI, as well as U.S. Customs or Interpol, might become involved if stolen items are suspected of being smuggled into or out of the country.

\section{E. Work for institutional and legislative support}

1. Work with the library's institutional administration to ensure their support for the prosecution of thieves. This support may range from the collection of evidence, which would be shared with prosecutors, to direct participation with the prosecution in preparation for and during the trial.

2. Work with appropriate institutional, local, and state groups to lobby for strengthening of state laws regarding library thefts and for diligent prosecution of such crimes. (See Appendix II for "Draft of Model Legislation: Theft and Mutilation of Library Materials.") 


\section{History of the guidelines}

The last revision of the "ACRL Guidelines Regarding Thefts in Libraries" was published in draft form in CGRL News 55, 5 (1994) and approved in June of that year. Just prior to the 1999 ALA Annual Conference, the ACRL Standards and Accreditation Committee and the RBMS Executive Committee asked the RBMS Security Committee to notify them of whether the guidelines required revision.

After a review and discussion of the guidelines at the Security Committee's 1999 Annual Conference meeting, both the ACRL Standards and Accreditation Committee and the RBMS Executive Committee were noti-

\section{F. Report to library- and book and manu- script-related groups}

1. Inform the local rare book, manuscript, and second-hand book sellers of the library's collecting areas and establish a procedure for quickly informing them of any theft that has occurred in your library. Thieves sometimes try to sell stolen property quickly, and sellers with knowledge of the library's collections can recognize, or at least be suspicious of, these genres of materials when they are offered.

2. Report the name of the LSO to the designated member of the RBMS Security Committee. Keep this person informed if successive LSOs are appointed.

3. Establish liaisons with appropriate Internet electronic mailing lists and national stolen and missing book databases (see Appendix I for "Networking Resources Directory for Protection and Recovery") so that thefts can be reported immediately upon discovery.

\section{G. Know and implement preventive se- curity measures in the library}

1. Implement the "ACRL Guidelines for the Security of Rare Book, Manuscript, and Other Special Collections," available from the ACRL office and published in CERL News (see RBMS Web site/Guidelines).

2. Assure that a unique ownership mark appears on all of the library's holdings; this will provide proof that materials, if stolen, belong to the library. RBMS strongly advocates the implementation of its marking guidelines for rare materials (see "ACRL fied that the guidelines would be revised. The guidelines were further discussed and revised at the 2000 Midwinter meeting and at the 2000 Annual Conference. In the fall of 2000 , a draft of the revision was mounted on the RBMS Web site. At the 2001 Midwinter meeting, additional changes were proposed at an open hearing, which were discussed and evaluated at the Security Committee's meeting. Those recommendations that the committee decided should be incorporated into the guidelines are reflected. in the document published below.

These guidelines are available on the Web at http:/ www.ala.org/acr/guides/theftdft.html.

Guidelines for the Security of Rare Book, Manuscript, and Other Special Collections," Appendix I). RBMS also strongly advocates describing distinctive characteristics of individual copies in cataloging notes as another means of identifying appropriate items.

3. When providing complete catalog records at the point of receipt is not possible, some form of ownership record, however brief, is recommended. It should contain a brief author/title statement and a description of at least several copy-specific features (e.g., binding, marks of previous ownership, completeness, and bookseller and auction house descriptions). These records of purchase, gift, and provenance are especially important when materials are going to be added to a cataloging backlog.

4. Eliminate cataloging backlogs. Though difficult, this is an essential step in enhancing the security of a library's collections. Even if the backlog cannot be entirely eliminated, each library should reduce its backlog as much as it can. Stolen books that have been described in detail are far more easily identified and recovered than those that are not. Use the catalog record to describe copy-specific characteristics and bibliographic information that helps to distinguish among editions, issues, and states. Create machinereadable records for local public access and the national bibliographic databases. Participate in bibliographic projects that record detailed bibliographic descriptions. 
5. Conduct regular inventories of both cataloged and uncataloged collections. This task is most effectively performed by staff members working in teams and should be conducted on a random basis. Proceeding through the collection in a predictable manner is not wise, since it may allow thieves to temporarily replace stolen materials. A simultaneous inventory of shelf list cards is also recommended, if this is not already a part of the procedure being followed. Inventories conducted even in small stages are valuable since they may reveal thefts (as well as misshelved books) and serve as a deterrent to any potential in-house thieves.

6. In Special Collections, record and verify (with photo ID) every user's name and address, and require them to complete a paper or electronic call slip and registration form, and to sign a reading room log. Whether housed in the collection or in the institutional archive, they should be kept for at least five years in order to be available to law enforcement authorities if thefts or vandalism later come to light. In order to safeguard reader confidentiality, access to filed or archived call slips should be restricted to the collection curator, division chief, and library director. Library policies and practices, especially in the course of investigating possible thefts, should not violate applicable federal, state, and local confidentiality laws. Library security officers should be familiar with all applicable laws governing personally identifiable information about library use. Library policy should require law enforcement officials to present a subpoena supporting a demand to examine user records, such as call slips and registration logs. If the demand is made under the federal Patriot Act, a subpoena is not required, but a warrant is, and library policy should require that it be produced.

7. Follow the management practices recommended in "ACRL Standards for Ethical Conduct for Rare Book, Manuscript, and Special Collections Librarians, with Guidelines for Institutional Practice in Support of the Standards," 2nd edition, 1994, available from the ACRL office, published in CERL News 54,4 (1993), and posted on the RBMS Web site.

8. Review materials in the library's general collections and open stacks for pos- sible transfer to special collections or to a caged, limited access section of the library. Library staff should consult the "ACRL Guidelines on the Selection of General Collection Materials for Transfer to Special Collections," 2nd edition, available from the ACRL office and published in CERL News 54,11 (1993), revised on June 23, 1999 and posted on the RBMS Web site. Some libraries have identified rare materials in the open stacks in the course of special projects, such as reporting to the English Sbort Title Catalogue, or working through a collection development policy using the Research Libraries Group Conspectus.

9. A recent theft or act of vandalism may give an indication of a building area, subject, or artifactual genre that will be the target of future theft or mutilation. If it is appropriate, transfer to a more secure area materials related to those already stolen or mutilated. Remember that subject relationships may cross genre lines. The theft or mutilation of printed books or manuscripts may indicate that other genres of materials containing similar subject matter will become the targets of thieves and vandals.

10. Maintain a shelflist, preferably in paper form for special collections, in a secure area of the library. If the shelflist is electronic, it should be equipped with software that makes it secure from tampering and be duplicated in a backup tape stored off site. Since the shelflist tells the librarian precisely where each book, pamphlet, tape, CD, etc. should be located, and because it contains copy-specific information about special collections materials, its maintenance and security are vital for detecting and recovering thefts.

11. Reader use of materials should be confined to a secure area monitored by staff trained in surveillance. Consult the "ACRL Guidelines for the Security of Rare Books, Manuscripts, and Other Special Collections," Section IV, for additional guidelines related to reading room security.

12. Install security cameras that cover Special Collections reading rooms and any access points that security professionals deem appropriate. If security cameras are supplied with tapes, the tapes should be retained for at least one month.

13. In conformity with applicable laws, formulate a policy regarding the physical detention of suspects. 


\section{Section II. Reacting to Library Theft}

Every case of theft poses unique challenges, and many details of a library's response to a theft must be left to the judgement of its LSO and its Security Planning Group. However, these are the general guidelines that ACRL recommends.

\section{A. If you observe or have been alerted to a theft in progress}

\section{Immediate actions}

- Discreetly call for security personnel or the police (or signal a colleague to do so) and engage the suspect in nonthreatening conversation in the hope that the suspect will remain in the reading room until help arrives.

- Do not confront a suspect with accusations. Behave with the suspect as you would with any patron, requesting that circulated materials be returned before the suspect leaves. If materials are missing, politely ask for them. The suspect may have made an honest mistake. If the suspect denies that $\mathrm{s} /$ he ever had the materials or that they were returned, do not press the issue and do not put yourself at risk of physical harm. Follow your local policy regarding the physical detention of suspects.

- If the suspect is about to leave and help has not yet arrived, try to verify his/her registration information (e.g., contact a listed reference or call information to verify a residential address) before s/he leaves.

- If a police officer finds reasonable cause that a theft has occurred, insist that the officer place the suspect under arrest. (Laws regarding grounds for arrest vary from state to state. Know the relevant laws of your state.) If there is evidence of theft (e.g., library materials hidden on the suspect's person), do not agree to the suspect's release in return for the suspect's assurances that $s$ /he will return to face charges. If the officer will not make an arrest, attempt to persuade the officer to detain the suspect until the officer can verify his/her identity and place of residence.

- At the first opportunity, describe in writing the suspect's physical appearance and an account of the entire event as witnessed and/or related. This document should be presented to law enforcement authorities when they arrive. Do not in any way alter materials that might be considered evidence.

- Notify the LSO

\section{B. If you discover a theft after it has oc- curred}

Notification

Immediately notify the LSO who will:

- Notify appropriate administrative officers

- Notify and serve as liaison with institutional security personnel as well as local law enforcement personnel

- Notify institutional Public Relations Office

\section{Gathering evidence}

The LSO will compile a list of missing items. (This does not mean that the entire library or collection needs to be inventoried.) However, after the immediate steps listed below have been taken, it is suggested that works similar to those that have been stolen be inventoried (see Section I.G.9, above). In consultation with the above groups of notified persons, gather all available evidence of theft. Such evidence should include:

- detailed, copy-specific descriptions of missing materials,

- chain of custody documentation for missing materials (including call slips or photocopies of them),

- indications of unauthorized physical access to restricted areas,

- report on any missing shelflist cards and call slips, and database tampering, and

- report on any indication of systematic patterns of loss of materials

\section{Action plan}

The LSO, in concert with appropriate library and institutional administration personnel, public relations personnel, security personnel, law enforcement (local, state, and federal, if necessary), and legal counsel will formulate a course of action that should include the following steps (in an order to be determined by those responsible for the process):

- consultation and cooperation with judicial and law enforcement efforts on behalf of the library,

- notification of appropriate stolen and missing books databases and other appropriate networks (see Appendix I for "Networking Resources Directory for Protection and Recovery"),

- notification of local and regional booksellers and appropriate specialist sellers,

- transfer of vulnerable items to a more secure location, 
- arrangement of appraisals upon discovery of missing items and, again, if they have been returned damaged,

- questioning of staff regarding any suspicious behavior by users or other persons,

- preparation of regular communications to staff about progress in the case, consistent with the investigation's integrity,

- preparation of news releases,

- preparation of responses by authorized library and institutional representatives to possible questions posed by the news media,

- instructions to all library and institutional staff on how to respond to news media inquiries, and

- maintenance of internal record of actions taken during the case's progress, from its discovery to its final disposition.

\section{APPENDIX I}

\section{Networking resources directory for pro- tection and recovery}

International Association of Professional Security Consultants. http://Www. iapsc.org; phone: (949) 640-9918; fax: (949) 640-9911. Includes a listing of professional security consultants with varying areas of expertise. Members of the organization cannot sell anything or represent any security firm.

"Library Security Resources: A Bibliography." http://www.libraryreference.org/security.html Although somewhat dated, this bibliography includes dozens of articles from various sources related to library security.

ACRL/RBMS Security Committee. c/o Association of College \& Research Libraries, $50 \mathrm{E}$. Huron St., Chicago, IL, 60611; phone: (800) 5452433, ext. 2523; fax: (312) 280-2520; e-mail: acrl@ala.org; homepage: http://www.ala.org/ acrl; RBMS homepage: http://www.rbms. nd.edu. Both ALA and ACRL have several publications related to designing a library security program.

Society of American Arcbivists. 527 S. Wells, Chicago, IL. 60607; phone: (312) 922-0140; fax: (312) 347-1452; e-mail: sfox@archivists. org; homepage: http://www.archivists.org. This organization has several books in print on special collections/archives security. It also has a security-related discussion list at saasecurity-1@cornell.edu. This list is open only to SAA members, however.
Library Security Officers List. Susan Allen, moderator. Closed nondiscussion electronic list for theft reporting and limited to library security officers only. For information, contact the owner at: sallen@.getty.edu

Exlibris electronic discussion list. E-mail: Exlibris@library.berkeley.edu. Electronic discussion list open to subscribers only, but subscription open to all. Has extensive Web archives that include security topics available at http://palimpsest.stanford.edu. For further information, contact moderator Everett Wilkie at e-mail: ewilkie@ix.netcom.com.

\section{Archives E Archivists Electronic Discussion} list. Often includes discussions about library security. Archives are available at the host site. Address for posting is archives@listserv. muohio.edu. Subscription address is listserv@ listserv.muohio.edu.

\section{APPENDIX |I}

The draft of proposed legislation presented below may have to be modified in order to conform with federal and state laws regarding search and seizure. Also, the recourse to civil law that is available to a detained suspect may differ from state to state, and the draft legislation may have to be modified in order to meet such potential challenges. However, the wording definitions should be adhered to; they have been formulated with the assistance of legal counsel. Nation-wide conformity to the definition of essential terminology in criminal legislation is desirable.

\section{Draft of model legislation: theft and mu- tilation of library materials}

\section{Declaration of purpose}

Because of the rising incidence of library theft and mutilation of library materials, libraries are suffering serious losses of books and other library property. In order to assure that research materials are available for public use, it is the policy of this state to provide libraries and their employees and agents with legal protection to ensure security for their collections. It is the policy of this state to affirm that local, state, and federal prosecution of crimes affecting books or other library property is executed with the same degree of diligence as is exercised in prosecution of crimes affecting other forms of property. Federal statute pertaining to stolen property is designed 
not only to implement federal-state cooperation in apprehending and punishing criminals who utilize, or cause to be utilized, channels of interstate commerce for transportation of property of which the owner has been wrongfully deprived, but also to deter original theft.

\section{Definition of terms}

"Library" means any public library; any library of an educational, benevolent, hereditary, historical, or eleemosynary institution, organization, or society; any museum; any repository of public or institutional records. "Book or other library property" means any book, plate, picture, photograph, print, painting, drawing, map, newspaper, magazine, pamphlet, broadside, manuscript, document, letter, public record, microform, sound recording, audiovisual material in any format, magnetic or other tape, catalog card or catalog record, electronic data processing record, artifact, or other documentary, written, or printed materials, or equipment, regardless of physical form or characteristics, belonging to, on loan to, or otherwise in the custody of a library.

\section{Proposed wording \\ Section I.a.}

Any person who willfully, maliciously, or wantonly writes upon, injures, defaces, tears, cuts, mutilates, or destroys any book, document, or other library property belonging to, on loan to, or otherwise in the custody of a library is guilty of a crime.

\section{Section I.b.}

The willful concealment of a book or other library property upon the person or among the belongings of the person or concealed upon the person or among the belongings of another while still on the premises of a library shall be considered prima facie evidence of intent to commit larceny thereof.

\section{Section I.c.}

The willful removal of a book or other library property in contravention of library regulations shall be considered prima facie evidence of intent to commit larceny thereof.

\section{Section I.d.}

The willful alteration or destruction of library ownership records, electronic or card catalog records retained apart from or applied directly to a book or other library property shall be considered prima facie evidence of intent to commit larceny of a book or other library property.

\section{Section II.a.}

An adult agent or employee of a library or that library's parent institution, whether or not that employee or agent is part of a security force, who has reasonable grounds to suspect that a person committed, was committing, or was attempting to commit the acts described in Section I may detain the suspect. Immediately upon detention, the library employee shall iclentify himself/herself and state the reason for his/her action. If, after the initial confrontation with the suspect, the adult agent or library employee has reasonable grounds to believe that at the time of detention that the person committed, was committing, or was attempting to commit the crimes set forth in Section I, said employee or agent may detain such a person for a time sufficient to summon a peace officer to the library. Said detention must be accomplished in a reasonable manner without unreasonable restraints or excessive force and may take place only on the premises of the library where the alleged crime occurred. Library premises include the interior of a building, structure, or other enclosure in which a library facility is located; the exterior appurtenances to such building structure, or other enclosure; and the land on which such building, structure, or other enclosure is located. Any person so detained by an employee or agent of a library shall promptly be asked to identify himself/herself by name and address. Once placed under detention, the suspect shall not be required to provide any other information nor shall any written and/or signed statement be elicited from the suspect until a police officer has taken the suspect into custody. The said employee or agent may, however, examine said property which the employee or agent has reasonable grounds to believe was unlawfully taken as set forth in Section I.b and/or I.C, or injured or destroyed as set forth in Section I.a and/or I.d. Should the detained suspect refuse to surrender the item for examination, a search may be made only of packages, shopping bags, handbags, or other property in the immediate possession of the person detained; no clothing worn by the suspect may be searched. 
The activation of an electronic article surveillance device as a result of a person exiting the premises or an area within the premises of a library where an electronic article surveillance device is located shall constitute probable cause for the detention of such person by such library or agent or employee of the library, provided that such person is detained only in a reasonable manner and only for such time as is necessary for an inquiry into the circumstances surrounding the activation of the device, and provided that clear and visible notice is posted at each exit and location within the premises where such device is located indicating the presence of an antitheft device. For purposes of this section, "electronic article surveillance device" means an electronic device designed and operated for the purpose of detecting the removal from the premises or a protected area within such premises, of any specially marked or tagged book or other library property.

\section{Section II.b.}

For the purposes of Section II.a, "reasonable grounds" shall include, but not be limited to, knowledge that a person has concealed or injured a book or other library property while on the premises of the library or the inability of the suspect to produce the library material for which there is a document proving that person had used but had not returned said material.

\section{Section II.c.}

In detaining a person who the employee or agent of the library has reasonable grounds to believe has committed, was committing, or was attempting to commit any of the crimes set forth in Section I, the said employee or agent may use a reasonable amount of nondeadly force when and only when such force is necessary to protect the employee or agent or to prevent the escape of the person being detained or the loss of the library's property.

\section{Section III.}

An adult agent or employee of a library who stops, detains, and/or causes the arrest of any person pursuant to Section II shall not be held civilly liable for false arrest, false imprisonment, unlawful detention, assault, battery, defamation of character, malicious prosecution, or invasion of civil rights of the person stopped, de- tained, and/or arrested, provided that in stopping, detaining, or causing the arrest of the person, the adult agent or employee had at the time of the stopping, detention, or arrest reasonable grounds to believe that the person had committed, was committing, or was attempting to commit any of the crimes set forth in Section I.

\section{Section IV.}

The fair market value of property affected by crimes set forth in Section I determines the class of offense: value under $\$ 500$ constitutes a misclemeanor; $\$ 500-\$ 5,000$ a Class I felony; above $\$ 5,000$, a Class II felony.

The aggregate value of all property referred to in a single indictment shall constitute the value thereof.

\section{Section V.}

A copy or abstract of this act shall be posted and prominently displayed in all libraries.

\section{Section VI.}

This act shall take effect upon passage.

\section{APPENDIX III: Related publications}

Association of College and Research Libraries. "Guidelines for the Security of Rare Book, Manuscript, and other Special Collections." In CERL News 60,9 (1999) and posted on the RBMS Web site.

Association of College and Research Libraries. "Guidelines on the Selection of General Collection Materials for Transfer to Special Collections." In CERL News 54,11 (1993), revised on June 23, 1999, and posted on the RBMS Web site.

Association of College and Research Libraries. "Standards for Ethical Conduct of Rare Book, Manuscript, and Special Collections Libraries and Librarians, with Guidelines for Institutional Practice in Support of the Standards." In CGRL News 54,4 (1993), and posted on the RBMS Web site.

Society of American Archivists. Libraries and Archives: An Overview of Risk and Loss Prevention, (1994).

Society of American Archivists. Protecting Your Collections: A Manual of Archival Security, (1995). 


\section{President's Program}

\section{Monday, June 17, 2:00 p.m.- 4:00 p.m. Poster session: 4:00 p.m.-5:00 p.m.}

Transformational Learning Communities: Claiming Our Future

Join your colleagues for a spirited forum featuring Dr. Barbara Leigh Smith, CoDirector of the National Learning Communities Project. Learn about the transformational nature of learning communities and the roles librarians can play in these dynamic activities and initiatives. Three librarians from diverse academic environments will also share their experiences related to the learning communities concept. A poster session will be conducted immediately following the program featuring creative learning communities that have been implemented in academic libraries across the country. Speakers: Barbara Leigh Smith, Co-Director, Pew Charitable Trusts National Learning Community Project; Theresa S. Byrd, Director of Libraries, Ohio Wesleyan University; Randy Burke Hensley, Head of Public Services, University of Hawaii at Manoa; Joan Lippincott, Associate Executive Director, Coalition for Networked Information.

\section{Preconferences}

\section{Tuesday, June 11-Friday, June 14, 2002, 8:30 a.m.-12:30 p.m.}

Rare Books and Manuscripts Section

New Occasions, New Duties: Changing Roles and Expectations in Special Collections

Change, both good and bad, is not made without some inconvenience. How does change affect and influence collection development, programming, public services, cataloging, teaching, recruitment, and scholarly research in rare books and manuscripts? The preconference will examine the different aspects and implications of change, and show ways in which special collections librarians can take advantage of change for their own use and development. Speakers include: Carla J. Stoffle, University of Arizona; James Vinson Carmichael, Jr., University of North Carolina at Greensboro; Robert L. Byrd, Duke University; Michael Lomax, Dillard University; Deborah Lipstadt, Emory University.

Fees: ACRL members: \$195; Non Members: \$250; Students: \$75; Late Fee (after May 10): \$50

Cover: The photograph is from the Lane Brothers Commercial Photographers Photographic Collection in the Special Collections Department, Pullen Library, Georgia State University. The collection spans the years 1920 to 1976. This photo of Peachtree Street at Ellis Street in Atlanta was taken in 1946. 
Friday, June 14, 2002, 8:00 a.m.-5:00 p.m.

From Expectations to Results: Library/Faculty Partnerships for Assessing Student Learning Outcomes

This preconference follows a two-year IMLS grant for faculty/librarian partnerships in assessing the Information Literacy Competency Standards for Higher Education. As a showcase for the grant recipients to distribute the findings and share their experiences, this full-day preconference will allow participants an invaluable opportunity to work with these experts. Speakers include: Ann Fiegen and Gabriela Sonntag, California State University at San Marcos; IMLS grant participants. Fees: ACRL members: \$195; ALA members: \$235; Non Members: \$275; Students: $\$ 85$

\section{Friday, June 14, 2002, 8:00 a.m.-5:00 p.m.}

Instruction Section

Instruction for First-Year Undergraduates: Developing Strategies to Facilitate their Transitions

Explore characteristics of first-year undergraduate students, examine what they are learning about information resources and strategies in high school, and investigate programmatic innovations at the institutional and library levels that meet first-year student needs. Develop or enhance your personal instructional approaches to working with first-year students with leadership from highly respected academic librarians, high school librarians, and university faculty. Speakers: Randy Burke Hensley, University of Hawaii at Manoa; Frances Jacobson Harris, University Laboratory (Urbana, IL) High School; Lisa Janicke Hinchliffe, Illinois State University; Margit Misangyi Watts, University of Hawaii.

Fees: ACRL members: $\$ 150$; ALA members: $\$ 195$; Non Members: $\$ 240$; Students: $\$ 95$

\section{Friday, June 14, 2002, 12:00-4:30 p.m.}

\section{Legislative Advocacy Workshop}

Legislative and public policy issues have a great impact on the environment in which librarians and academic libraries operate. Hear practical views on effectively managing library legislative issues as outstanding, long-time library advocates share their experiences and sage advice on the art of persuasion. Speakers: Charles Beard, State University of West Georgia; Lynne Bradley, ALA Washington Office; Jill Fatzer, University of New Orleans; James Neal, Columbia University; Mary Margaret Oliver, former Georgia state legislator; Christy Vernon, ALA Committee on Legislation. Fees: ACRL members: $\$ 50$; ALA members: $\$ 50$; Non Members: $\$ 50$; Students: $\$ 50$

Editor's note: Locations for programs and meetings will be available May 1, 2002, on the ALA Web site. Go to http://www.ala.org/events/annual2002/welcome.html and click Event Planner. If you have registered for the conference, you can check meeting locations. 


\section{Programs}

\section{Saturday, June 15}

\section{ACRL Ethics Committee}

10:30 a.m.-12:00 p.m., Track: Staff / Subtrack: Management

\section{Ethical Dilemmas and Libraries: An Analytic Model}

Discuss the utility of a principle-based ethical model as it might apply to ethical problems encountered by library staff and administrators. The speaker will use the model to analyze the ethical problems recently encountered at Emory University in co-sponsoring an exhibit of photographs and postcards of lynchings in the United States from 1870-1960. The exhibit is currently mounted at the Martin Luther King Jr. National Historic Site and Emory assisted in developing educational materials and programs. Speaker: John Banja, Center of Ethics, Emory University.

\section{ACRL African American Studies Section (AFAS)}

1:30-3:30 p.m., Track: Collection Management / Subtrack: Selection, Evaluation, \& Preservation When Old is New: The Art of Creating New African-American Special Collections The past few years have witnessed a resurgence of interest in African American special collections. Several new research libraries and centers have been created. Well-established libraries that had not previously collected African American materials have begun to develop research collections in this area. Learn about these new collections and examine methods of acquiring materials, developing donor bases, conducting outreach, and collaborating with other collections. Speakers: Randall K. Burkett, African-American Studies Bibliographer, Emory University; Lucelia Flood-Partridge, Auburn Avenue Research Library on African-American Culture and History, Atlanta-Fulton Public Library System; Pearl Woolridge, African American Research Library and Cultural Center, Von D. Mizelle Library; Moderator: Karen L. Jefferson, Head, Archives and Special Collections, Atlanta University Center

\section{ACRL Arts Section (ARTS)}

1:30 p.m.-5:30 p.m., Track: Collection Management / Subtrack: Selection, Evaluation, \& Preservation

\section{Artist's Books: Creating, Publishing \& Collecting}

Hear about the evolution of the artist book from creation to production to acquisition. Learn more about each aspect of the process from individuals directly involved. Following the panel discussion, Ms. Steven will conduct tours of the Atlanta College of Art Library artists' book collection (located at the Woodruff Arts Center) and Mr. Freeman will conduct small group tours of Nexus Press. Directions will be provided at the program. Speakers: Johanna Drucker, Robertson Professor of Media Studies and Director of the Interdisciplinary Program in Media Studies, University of Virginia; Brad Freeman, Director of Production, Nexus Press, Atlanta Contemporary Art Center, and Editor, Journal of Artists Books; Arthur H. Jaffe, private collector; James A. Findlay, Librarian/Curator, Biennes Center for the Literary Arts, Broward County Main Library; Moira Steven, Library Director, Atlanta College of Art Library.

\section{ACRL Distance Learning Section (DLS)}

1:30 p.m.-3:30 p.m., Track: Services and Programs / Subtrack: Information Literacy and Instruction

\section{E-Research Companies: Value-Added or Virtually Redundant?}

A discussion for professionals concerned about plagiarism, duplication of resources, marketing of library services, and information competency. Speakers: James Neal, Columbia University Libraries; Troy Williams, Questia Media, Inc; Dr. Morris Shepard, Authority Finder; Susan Swords Steffen, Elmhust College; Moderator: Michael McManus, Co-Anchor, CNN Student News. 


\section{ACRL Education and Behavioral Sciences Section (EBSS)}

1:30 p.m.-3:30 p.m., Track: Staff / Subtrack: Staff Development

Games Academics Play: Mastering the Social Psychology of Faculty/Librarian Relationships

This program brings together faculty library users and librarians to offer a candid exploration of faculty/librarian relationships in academic settings. Examine faculty behavior, perceptions of, and attitudes towards librarians and their role in learning and academic support. Learn more about faculty needs and learn strategies to foster mutual communication and understanding in the academic environment. Speakers: John M. Budd, School of Information Science and Learning Technologies, University of Missouri at Columbia; Lars Christiansen, Department of Sociology, Augsburg College; Mindy Stombler, Department of Sociology, Georgia State University; James Emshoff, Department of Psychology, Georgia State University.

\section{ACRL University Libraries Section (ULS)}

1:30 p.m.-3:30 p.m., Track: Staff / Subtrack: Management

Minding the Generation Gap: Learn How to Communicate and Work Together Across Generations

Like other organizations, academic libraries face challenges posed by generational differences in their workforce. Baby boomers, Gen Xers, and Gen Yers bring varying work ethics, expectations, and goals to the library. Learn how to recognize these differences to promote communication and facilitate better working relationships. Speakers: Sheila Creth, University of lowa; Faye Backie, Michigan State University; Crit Stuart, Georgia Tech; Jody Fagan, Southern Illinois University.

\section{SPARCIACRL Forum, Atlanta}

1:30 p.m.-3:30 p.m.

\section{Open Access to Scholarship: Paths for Libraries}

At this SPARC/ACRL Forum, participants will explore ways libraries can support the most promising open access initiatives, including: institutional respositories; open-access journals; and other new ventures. ACRL's new Scholarly Communications Committee will launch at the Forum with a presentation on its goals for the next two years. We hope to see you there!

\section{ACRL Law and Political Science Section (LPSS)}

\section{2:00 p.m. -4.00 p.m.}

Track: Services and Programs / Subtrack: Information Literacy and Instruction

\section{Librarians in the Big Leagues: Are You Ready for the Teaching Academy?}

Many of our institutions are placing greater emphasis on the teaching academy as a means of promoting and improving teaching skills. This program explores two aspects of the teaching academy. First, how can librarians help classroom teachers improve their teaching through the use of the library? Second, how can librarians receive training to become better teachers? Librarians now have the opportunity to become engaged in this cutting-edge practice. Speakers: Sally M. Ives, Director of the Faculty Center for Teaching, University of North Carolina at Charlotte; Linda C. Smith, Interim Dean, Graduate School of Library and Information Science, University of Illinois at Urbana-Champaign; Susan Searing, Library and Information Science Library, University of Illinois at Urbana-Champaign.

\section{ACRL Literatures in English Section (LES)}

2:00 p.m.-4:00 p.m., Track: Services and Programs / Subtrack: Information Literacy and Instruction

\section{Teaching Literary Research: Challenges in a Changing Environment}

Literary studies and their supporting library collections can be simultaneously conservative and cuttingedge. In no other discipline does "the book" continue to hold so much importance. Yet networks, databases, and digital works all impact the research process of the literary scholar. The field has also embraced new methodological approaches in recent years. Learn about challenges instruction librarians face in this changing environment when teaching the research process to users. Speakers: James Bracken, Ohio State University; James Harner, Department of English, Texas A\&M University; Helene Williams, Widener Library, Harvard University; William Wortman, Miami University. 


\section{Sunday, June 16}

\section{ACRL Anthropology and Sociology Section (ANSS)}

8:30 a.m.-12:00 p.m., Track: Staff / Subtrack: Staff Development

\section{Shamanism: Implications for Revisioning Librarianship}

Examine shamanism from three different perspectives. A cultural anthropologist and professor of religion will define the term, look at its historical development in American culture, and comment on modern-day applications in contemporary societies. A medical anthropologist will examine the healing aspects of shamanism in earlier eras and today. A sociologist and professor of library science will offer a sociological perspective on shamanism and why it appeals to high-tech information-driven cultures like our own. Speakers: Dr. Delia Easton, Center for Disease Control and Prevention; Gary M. Laderman, Department of Religion, Emory University; Sydney J. Pierce, School of Library Science, Catholic University.

\section{ACRL Asian, African and Middle Eastern Section (AAMES)}

8:30 a.m.-12:00 p.m., Track: Collection Management / Subtrack: Authors and Literary Sessions

\section{Mission Brief: The Research Legacies of Missionary Literatures}

Hear from a panel of research librarians familiar with the history of mission work in the geographic regions of Asia, Africa, and the Middle East. Learn about the unique evolution and composition of this class of literature (including newspapers and periodicals), factors that influence its production and dissemination. Learn more about the historic and continuing impact on popular Western perceptions of these lands, the rise of area studies, and research applications of this diverse body of data. Speakers: Haipeng Li, Oberlin College Library; Norman Ross, Norman Ross Associates; Dr. Gregory Finnegan, Tozzer Library, Harvard University; Russel Kracke, American Theological Library Association.

\section{ACRL College Libraries Section (CLS)}

9:30 a.m.-11:00 a.m., Track: Services and Programs / Subtrack: Services

\section{Will the Real Customer Please Stand Up? Designing Services for 21st-Century} Users

Learn about the range of issues related to customer service outreach and the delivery of assistance. Find out where our customers are, what they are doing, and what they expect from library services. Hear advice from librarians who have studied their users and designed services for their 21st-century clientele. Speakers: Barbara Valentine, Reference and Systems Librarian, Linfield College; Janet Cotrell, Director of Information Access, Kenyon College; Maryann Hight, Instructional Services Librarian, Bates College; Rachel Cheng, Associate University Librarian, Wesleyan University.

\section{ACRL Copyright Committee}

\section{9:30 a.m.-12:00 p.m., Track: Issues and Updates / Subtrack: Intellectual Freedom}

Pirates on the Commons: Legal \& Political Assaults on Information Access by the Expanding Domain of Copyright

Increase your awareness of the politics of copyright law and fair use and encourage involvement in copyright politics. Learn about the negative impact of recently enacted laws and judicial opinions; learn about their effect on scholarship, teaching, and libraries. The relationship between intellectual freedom and copyright will also be explored. Speakers: L. Ray Patterson, Pope Brock Professor of Law, University of Georgia; Carrie Russell, Copyright Specialist, ALA; Mary M. Case, Director of the Office of Scholarly Communication, ARL; Lawrence Lessig, Professor of Law, Stanford Law School. 


\section{ACRL Intellectual Freedom Committee}

10:30 a.m.-12:00 p.m., Track: Issues and Updates / Subtrack: Intellectual Freedom

\section{Pornography in Libraries: Sexual Harassment?}

The availability of sexually explicit materials on the Internet has created new challenges for the library as a workplace. Can unrestricted Internet access create a sexually hostile work environment for library staff? A recent ruling by the Minneapolis EEOC suggests that it may. This brings two deeply held library values - intellectual freedom and equitable workplaces - into apparent conflict. Join us for a timely and stimulating discussion. Speakers: Camille Hebert; Robert CornRevere, Hogan \& Hartson; Elizabeth Williams.

\section{ACRL Racial \& Ethnic Diversity Committee}

10:30 a.m.-12:00 p.m., Track: Services and Programs / Subtrack: Public Services

\section{Outreach in the Academic Library}

Learn about academic library programs developed to create a bridge between university libraries, community colleges, and the $\mathrm{K}-12$ community. Explore ways to reach out to campus communities and communities-at-large and find out how to create a "seamless education" to bridge students and libraries. Discover how to provide the personal and academic support necessary in the students' quest to succeed in an academic environment. Job Shadow Day will be one program highlighted. Speakers: Lothar Spang, Librarian, Wayne State University Adamany Undergraduate Library; Elaina Norlin, Assistant Librarian, University of Arizona Library; Gloria L. Rhodes, Outreach Librarian, San Diego State University.

\section{ACRL Instruction Section (IS)}

1:30 p.m.-3:30 p.m., Track: Services and Programs / Subtrack: Information Literacy and Instruction

\section{Building Premier Learning Communities: Strategies for Successful Library Involvement}

Learning communities have been described as "an intentional process of redesigning curriculum and bringing faculty and students together to create more coherent and collaborative learning environments." This program will investigate the components of successful learning communities and suggest specific strategies for library involvement. Speakers: Nancy Shapiro, Associate Vice Chancellor, Academic Affairs, University System of Maryland; Martha Henn McCormick, Indiana University-Purdue University Indianapolis; James B. Young, George Mason University; Kimberly B. Kelley, University of Maryland.

\section{ACRL Rare Books and Manuscripts Section (RBMS)}

\section{1:30 p.m.-5:30 p.m., Track: Digital Libraries / Subtrack: Access and Services}

The Emergence of Digital Scholarship: New Models for Librarians, Archivists and Humanists

Humanities scholars are increasingly building thematically-based digital research collections comprising primary resources as well as critical secondary resources. Building these internationally accessible collections requires close collaboration among humanists, librarians, and archivists at repositories holding dispersed and related materials. Issues involving access, ownership, collaboration, rights, user expectations, and non-traditional user populations will be discussed. Speakers: Martha Nell Smith, Director of the Maryland Institute for Technology in the Humanities, University of Maryland; Morris Eaves, Professor of English, University of Rochester; Daniel V. Pitti, Institute for Advanced Technology in the Humanities, University of Virginia; John Unsworth, Institute for Advanced Technology in the Humanities, University of Virginia; Rutherford W. Witthus, Curator of Literary and Natural History Collections, University of Connecticut. 


\section{ACRL Slavic and East European Section (SEES)}

1:30 p.m.-3:30 p.m., Track: Staff / Subtrack: Staff Development

\section{What Do You Do When You Don't Have a Subject Specialist?}

Research needs strain your library scope? SEES explores the issue. The Slavic \& East European Section demonstrates the problem of faculty and students' research interests going beyond the scope of the library. Libraries can lack specific subject specialists, language expertise, or the area may just not be one previously collected. Speakers include a historian requiring more material than his home library can provide, and librarians who work to help that situation. Speakers: Helen Sullivan, Head of the Slavic Reference Service, University of Illinois at Urbana-Champaign; Erika Banski, Slavic Librarian, University of Alberta; Gregory Ference, Department of History, Salisbury University.

\section{Monday, June 17}

\section{ACRL Science and Technology Section (STS)}

8:30 a.m.-12:00 p.m., Track: Issues and Updates / Subtrack: Digital Society

\section{Old, New, Borrowed, and Blue: Science \& Technology Intellectual Property}

\section{Issues in the Digital Age}

Concerned about the intellectual property issues that affect the creation and distribution of scientific and technical information? Here's your chance to learn more about how copyright, fair use of research materials, licensing restrictions on information use, and patents are affecting access to scientific information. A one-hour poster session follows the panel presentations. Speakers: Dr. Alan Covich, Professor, Department of Fishery and Wildlife Biology, Colorado State University; Linda S. Dobb, Executive Vice President, Bowling Green State University; Carrie Russell, Copyright Specialist, American Library Association.

\section{ACRL Women's Studies Section (WSS)}

9:00 a.m.-12:00 p.m., Track: Issues and Updates / Subtrack: Digital Society

\section{Women, Technology, and Libraries}

Little attention is paid to issues that surround women's use and understanding of technology or how women library employees can use technology to advance their careers. Find out how to create an effective technology learning environment. Discover how we as women are refining ourselves and our profession and learn what women seeking career growth in information technology need to know. Speakers: Dolores Fidishun, Head Librarian, Penn State Great Valley School of Graduate Professional Studies; Kristin H. Gerhard, Collections Officer, lowa State University; Kelly Barrick Hovendick, Womens Studies \& Sociology Specialist, Syracuse University.

\section{ACRL Western European Studies Section (WESS)}

\section{0:30 a.m.-12:00 p.m., Track: Digital Libraries / Subtrack: Access \& Services}

\section{Mapping the Future of Historical Scholarship About Europe}

Find out about the current developments and future trends in the digitization of historic course materials, including their creation and accessibility. Discover how to identify online texts, digital images, and data sets that are relevant to research on Western Europe. Participate in a forum and discuss issues such as preservation of materials, cost, and viability of digital projects, collaboration, sharing of resources, and special users' needs. Speakers: Humphrey Southall, Reader in Geography, University of Portsmouth; Karl Longstreth, Social Sciences Librarian. University of Michigan; Richard Hacken, European Studies Bibliographer, Brigham Young University. 


\section{Special Events/Tours}

Friday, June 14, 6:00-9:00 p.m.

College Libraries Section

Friday Night Feast (sponsored by Haworth)

Mary Mac's Tea Room, 224 Ponce de Leon Avenue NE. Contact Paul Frisch for more information

(frisp@lake.ollusa.edu). Dinner is free but limited to the first 60 members to sign up.

Friday, June 14, 6:00-10:00 p.m.

Instruction Section

\section{IS Dinner}

Gordon Biersch Brewery Restaurant, 848 Peachtree Street, $\$ 34$. Contact Nancy Reinhold for more information (libngr@emory.edu). To register, send check payable to ACRL to Mary Jane Petrowski, IS Dinner, ACRL, 50 East Huron Street, Chicago, IL 60611.

\section{Saturday, June 15, 11:30 a.m.-12:30 p.m.}

Law and Political Science Section

Marta Lange/CQ Award Luncheon.

Contact Lynne Rudasill (rudasill@uiuc.edu) for more information.

\section{Saturday, June 15, 3:30 p.m.-5:30 p.m.}

University Libraries Section

Reception (following conference program)

Saturday, June 15, 4:15 p.m.-9:00 p.m.

Literatures in English Section

Reception

Sunday, June 16, 12:30 p.m.-1:30 p.m.

Instruction Section

LIRT/IS 25th Anniversary Reception

\section{Sunday, June 16, 6:00 p.m.-9:00 p.m.}

Slavic and East European Section \& Western European Studies Section

\section{WESS/SEES Cruise}

Stone Mountain Park, \$30. To register, send check payable to ACRL to Mary Jane Petrowski, WESS/SEES Cruise, ACRL, 50 East Huron Street, Chicago, IL 60611.

\section{Monday, June 17, 8:30 a.m.-1:00 p.m.}

Community and Junior College Libraries Section

Tour of the new LRC at Georgia Perimeter College, Dunwoody Campus. Box lunch provided.

Contact David Voros (dvoros@|ccc.edu) for additional information.

\section{Monday, June 17, 4:30 p.m.-6:00 p.m.}

ACRL Academic/Research Librarian of the Year Award Reception

Reception to be held in same hotel as the ACRL President's Program. 


\section{Ac Meetings}

Editor's note: This list was current as C\&RL News went to press. Be sure to check the program book for the final schedule and location of meetings.

\section{ACRL Board of Directors}

First meeting: Saturday, June 15, 2:00-4:00 p.m. Second meeting: Tuesday, June 18, 1:00-4:30 p.m.

\section{ACRL General}

ACRL Academic/Research Librarian of the Year Award Reception: Monday, June 17, 4:30-6:00 p.m.

Chapters Council: Sunday, June 16, 8:30-11:00 a.m. Leadership Council: Friday, June 14, 2:00-4:00 p.m. New Leader Orientation: Friday, June 14, 11:30 a.m. $-2: 00$ p.m.

President's Program: Monday, June 17, 2:00-4:00 p.m. "Transformational Learning Communities: Claiming Our Future"; Poster session: 4:00-5:00 p.m.

Sections Council: Friday, June 14, 4:30-5:30 p.m.

\section{ACRL Divisional Committees}

@ Your Library: Tuesday, June 18, 8:00-9:30 a.m. AASL/ACRL Information Literacy Task Force, Saturday, June 15, 4:30-6:30 p.m.

Best Practices in Information Literacy Invitational Conference: Tuesday, June 11, 4:30-7:30 p.m.; Wednesday, June 12, 8:00 a.m. $-5: 00$ p.m.; Thursday, June 13, 8:00 a.m.-5:00 p.m.

Best Practices Project Team: Saturday, June 15, 8:30-11:00 a.m.

Budget and Finance: Saturday, June 15, 8:30 a.m12:30 p.m.; Monday, June 17, 8:30 a.m. $-12: 30$ p.m.

Bylaws Committee: Monday, June 17, 9:30-11:00 a.m.

Conference Program Planning-Toronto, 2003: Saturday, June 15, 8:00-9:00 a.m.

Copyright: Sunday, June 16, 8:30-9:30 a.m. Program: 9:30 a.m.-12:00 p.m. "Pirates on the Commons: Legal and Political Assaults on Information Access by the Expanding Domain of Copyright."

Council of Liaisons, Saturday, June 16, 11:30 a.m.1:00 p.m.

Ethics Committee: Saturday, June 15, 10:30 a.m12:00 p.m. "Ethical Dilemmas and Libraries: An Analytic Model." Saturday, June 15, 4:30-6:00 p.m.

Focus on the Future: Monday, June 17, 11:00 a.m.1:30 p.m.; Open hearing: "Academic Library Futures Forum," Sunday, June 16, 2:00-4:00 p.m.
Government Relations: Monday, June 17, 9:30 a.m. $-12: 30$ p.m.

Information Literacy Advisory: Saturday, June 15, 2:00-4:00 p.m.

Institute for Information Literacy (IIL) Advisory: Friday, June 14, 8:00 a.m.-5:30 p.m.; Monday, June 17, 8:30-11:00 a.m.

Institute for Information Literacy (ILL) Immersion 2002 Faculty: Thursday, June 13, 8:00 a.m.-5:30 p.m.

Intellectual Freedom: Sunday, June 16, 10:30 a.m.12:00 p.m. "Pornography in Libraries: Sexual Harassment?"; Sunday, June 16, 2:00-4:00 p.m.

International Relations: Sunday, June 16, 8:3011:00 a.m.

Membership: Sunday, June 16, 4:30-5:30 p.m.

National Conference Executive CommitteeCharlotte, 2003: Saturday, June 15, 11:30 a.m.1:30 p.m.

National Conference Subcommittees-Charlotte, 2003: Monday, June 17, 8:30-11:00 a.m.

Nominations: Sunday, June 16, 8:00-9:00 a.m.

President's Program Planning-2002: Saturday, June 15, 9:00 a.m.-5:30 p.m.; Monday, June 17, 9:30-11:00 a.m.

President's Program Planning-2003: Saturday, June 15, 9:30-11:00 a.m.; Monday, June 17, 8:30-11:00 a.m.

Professional Development: Saturday, June 15, 9:30 a.m. $-12: 30$ p.m.

Publications: Saturday, June 15, 8:00-9:00 a.m; Monday, June 17, 8:30-11:00 a.m.

Racial and Ethnic Diversity: Sunday, June 16, 10:30 a.m.-12:00 p.m. "Outreach in the Academic Library."

Research: Saturday, June 15, 11:30 a.m.-12:30 p.m.

Scholarly Communication: Sunday, June 16, 8:0011:00 a.m.

SPARC/ACRL Forum: Saturday, June 15, 1:30-3:30 p.m., "Open Access to Scholarship: Paths for Libraries."

Standards and Accreditation: Sunday, June 16, 2:00-5:30 p.m.

Statistics: Friday, June 14, 4:30-5:30 p.m.

Status of Academic Librarians: Saturday, June 15, 2:00-5:30 p.m.; Sunday, June 16, 11:30 a.m.12:30 p.m.

Web Usability Study: Saturday, June 15, $9: 30$ a.m.1:00 p.m.; Sunday, June 16, 4:00-8:00 p.m.; Monday, June 17, 1:00-5:00 p.m. 


\section{ACRL Chapters}

Chapters Council: Sunday, June 16, 8:30-11:00 a.m.

\section{ACRL Editorial Boards}

Choice: Sunday, June 16, 8:30-11:00 a.m.

Choice Reviews Online Focus Group: Monday, June 17, 7:00-9:00 a.m. (closed)

College \& Research Libraries: Saturday, June 15, 11:30 a.m. $-12: 30$ p.m.

College \& Research Libraries News: Sunday, June 16, 8:30-11:00 a.m.

New Publications Advisory Board: Sunday, June 16, 11:30 a.m. $-12: 30$ p.m.

Publications in Librarianship: Saturday, June 15, 2:00-4:00 p.m.

RBM Editorial Board: Sunday, June 16, 9:30 a.m.12:30 p.m.

\section{ACRL Sections}

Sections Council: Friday, June 14, 4:30-5:30 p.m.

\section{African-American Studies Librarians Section}

Program: Saturday, June 15, 1:30-3:30 p.m. "When Old is New: The Art of Creating New African American Special Collections."

Executive: Saturday, June 15, 9:30-11:00 a.m.

General Membership: Saturday, June 15, 3:30-5:30 p.m.

Cataloging Issues Discussion Group: Sunday, June 16, 9:30-11:00 a.m.

Constitution and Bylaws: Saturday, June 15, 8:009:00 a.m.

Policy and Research: Saturday, June 15, 8:00-9:00 a.m.

Program Planning-2002: Saturday, June 15, 8:009:00 a.m.

Publications: Saturday, June 15, 8:00-9:00 a.m.

Standing Committees: Saturday, June 15, 8:009:00 a.m.

Strategic Planning: Saturday, June 15, 8:00-9:00 a.m.

\section{Discussion Groups}

(All section discussion groups are listed with their sections.)

Australian/Canadian/New Zealand Studies: Sunday, June 16, 11:30 a.m.-12:30 p.m. Topic: "CAVAL: An Australian, Canadian, New Zealand Discussion Group."

Consumer and Family Studies: Sunday, June 16, 4:30-5:30 p.m. Topic: "Changes and Trends in Colleges of Consumer and Family Studies."

Electronic Reserves: Sunday, June 16, 8:30-11:00 a.m. Topics: "E-Resenves at UT-Austin: A Distributed Model"; and "Copyright Management."

E-Text: Sunday, June 16, 2:00-4:00 p.m. Topic: "Open Archives Initiative: Metadata Harvesting."

Fee-based Information Services Centers in Academic Libraries: Saturday, June 15, 2:004:00 p.m. Topic: "The Future of Fee-Based Services." Sunday, June 16, 4:30-5:30 p.m. Topic: "Bridging the Gap for Distance Learners: A Look at the Role of Traditional Document Delivery Services vs. Fee-Based."

Heads of Public/Readers Service: Sunday, June 16, 4:30-5:30 p.m.

Library Development: Saturday, June 15, 8:3011:00 a.m. Topic: "Fundraising for College and University Libraries."
Media Resources: Sunday, June 15, 9:30-11:00 a.m. Topic: Metadata for Media/Media Content Related to Curriculum."

MLA International Bibliography in Academic Libraries: Saturday, June 15, 9:30 a.m.-12:30 p.m. Topic: "The Gale Group, Ovid Technologies/ Silverplatter Information, OCLC."

Personnel Administrators and Staff Development Officers: Saturday, June 15, 9:30-11:00 a.m.; Sunday, June 16, 9:30-11:00 a.m. Topic: "Current Issues in Human Resources and Staff Development."

Philosophy, Religion, and Theology: Sunday, June 16, 2:00-5:30 p.m. Topic: Open Discussion.

Popular Culture in Libraries: Sunday, June 16, 4:30-5:30 p.m. Topic: "J.R.R. Tolkein: Collecting the Author of the Century."

Scholarly Communication: Sunday, June 16, from 2:00-4:00 p.m. Topic: Developing the ACRL Scholarly Communications Agenda.

Team-Based Organizations: Saturday, June 15, 11:30 a.m.-12:30 p.m.

Undergraduate Librarians: Monday, June 17, 8:30-11:00 a.m. 


\section{Anthropology and Sociology Section}

Program (Joint program with EBSS): Saturday, June 15, 1:30-3:30 p.m. "Games Academics Play: Mastering the Social Psychology of Faculty/ Librarian Relationships."

Program: Sunday, June 16, 8:30 a.m.-12:00 p.m. "Shamanism: Implications for Revisioning Librarianship."

Bibliography: Saturday, June 15, 2:00-4:00 p.m.; Sunday, June 16, 2:00-4:00 p.m.

Executive: Saturday, June 15, 8:00-9:00 a.m.; Monday, June 17, 9:30 a.m.-12:30 p.m.

Anthropology Librarians Discussion Group: Sunday, June 16, 4:30-5:30 p.m.

Bibliography: Saturday, June 16, 2:00-5:30 p.m.

Conference Program Planning-Toronto, 2003: Monday, June 17, 8:00-9:00 a.m.

Criminal Justice/Criminology Librarians Discussion Group: Saturday, June 15, 4:30-5:30 p.m.

Liaison: Saturday, June 15, 9:30-11:00 a.m.

Membership: Sunday, June 16, 2:00-4:00 p.m.

Nominating 2003: Monday, June 17, 8:009:00 a.m. (closed)

Publications: Saturday, June 15, 2:00-4:00 p.m.

Review and Planning: Saturday, June 15, 9:3011:00 a.m.

Sociology Librarians Discussion Group: Saturday, June 15, 11:30 a.m.-12:30 p.m.

Subject and Bibliographic Access: Saturday, June 15, 9:30-11:00 a.m.

\section{Arts Section}

Program (Co-sponsored by RBMS. ARLIS/SE, and GLBTRT): Saturday, June 15, 1:30-5:30 p.m. "Artist's Books: Creating, Publishing, and Collecting."

Program (Joint program with LITA/Technology in the Arts): Sunday, June 16, 10:30 a.m.-12:00 p.m. "The Documents of September 11 and the Search for Stable Ground."

Program (Co-sponsored by RBMS): Sunday, June 16, 1:30-5:30 p.m. "The Emergence of Digital Scholarship: New Models for Librarians, Archivists, and Humanists."

Executive Committee and Membership: Sunday, June 16, 8:30-10:30 a.m.

All Committees: Saturday, June 15, 9:30 a.m.-12:30 p.m.

Dance Librarians Discussion Group: Monday, June 17, 9:30-11:00 a.m.

Film and Broadcast Librarians Discussion Group: Saturday, June 15, 4:30-5:30 p.m.
Performing Arts Librarians Discussion Group: Sunday, June 16, 4:30-6:00 p.m.

\section{Asian, African, and Middle Eastern Section}

Program: Sunday, June 16, 1:30-3:30 p.m. "Mission Brief: The Research Legacies of Missionary Literatures."

Executive and Committee: Sunday, June 16, 11:30 a.m. $-12: 30$ p.m.

Program Planning 2003: Friday, June 14, 9:3011:00 a.m.

Publishers Liaison Committee: Friday, June 14, 2:00-4:00 p.m.

\section{College Libraries Section}

Program: Sunday, June 16, 9:30-11:00 a.m. "Will the Real Customer Please Stand Up? Designing Services for 21 st-Century Users."

Executive: Saturday, June 15, 8:30-11:00 a.m. (new chairs and officers orientation); Tuesday, June 18, 8:30-11:00 a.m.

Business: Sunday, June 16, 9:00-9:30 a.m.

CLIP Notes: Saturday, June 15, 11:30 a.m.-12:30 p.m.

College Library Directors Discussion Group: Sunday, June 16, 2:00-4:00 p.m.

Communications: Saturday, June 15, 11:30 a.m.12:30 p.m.

Conference Program Planning-Atlanta, 2002: Saturday, June 15, 11:30 a.m.-12:30 p.m.

Conference Program Planning-Toronto, 2003: Saturday, June 15, 9:30-11:00 a.m.; Monday, June 17, 9:30-11:00 a.m.

Continuing Education: Monday, June 17, 9:3011:00 a.m.

Leadership: Monday, June 17, 9:30-11:00 a.m.

Medium-Sized Academic Libraries Discussion Group: Monday, June 17, 9:30-11:00 a.m. Topic: "Responding to Change and Reference Services."

Membership: Monday, June 17, 8:00-9:00 a.m.

Research for College Librarianship: Monday, June 17, 9:30-11:00 a.m.

Standards: Friday, June 14, 4:30-5:30 p.m.; Saturday, June $15,11: 30$ a.m. $-12: 30$ p.m.

\section{Community and Junior College Libraries Section}

Program (Joint program with DLS): Saturday, June 15, 1:30-3:30 p.m. "E-Research Companies: Value-Added or Virtually Redundant?" 
Executive: Sunday, June 16, 11:30 a.m.-12:30 p.m.; Tuesday, June 18, 8:30-11:00 a.m.

All Committees (Bibliographic Instruction, Library/Media Technician Training, Library Resources Review, Membership/Communication, Planning and Procedures, Research and Publications, Technology): Sunday, June 16, 2:00-4:00 p.m.

CJCLS/NCLR Joint Discussion Group: Saturday, June 15, 10:00 a.m.-12:00 p.m.

Membership and EBSCO Awards: Saturday, June 15, 8:30-9:30 a.m.

New LRC Tour and Box Lunch: Monday, June 17, 8:30 a.m-1:00 p.m. Georgia Perimeter College, Dunwoody Campus.

Nominating 2003: Sunday, June 16, 2:004:00 p.m. (closed)

Standards: Friday, June 14, 2:00-4:00 p.m.

\section{Distance Learning Section}

Program (Joint program with LITA): Saturday, June 15, 10:30 a.m.-12:00 p.m. "User Authentication Strategies in Multi-Institutional Environments."

Program (Joint program with CJCLS): Saturday, June 15, 1:30-3:30 p.m. "E-Research Companies: Value-Added or Virtually Redundant?"

Executive: Sunday, June 16, 2:00-5:30 p.m.

All Committees: Sunday, June 16, 1:30-5:30 p.m.

General Membership Discussion Group: Monday, June 17, 8:30-11:00 a.m.

\section{Eduçation and Behavioral Sciences Section}

Program (Joint program with ANSS): Saturday, June 15, 1:30-3:30 p.m. "Games Academics Play: Mastering the Social Psychology of Faculty/ Librarian Relationships."

Executive: Friday, June 14, 7:00-9:00 p.m.

Advisory Council: Sunday, June 16, 9:30 a.m.12:30 p.m.

Conference Program Planning-Atlanta, 2002: Friday, June 14, 3:00-4:00 p.m.

Conference Program Planning-Toronto, 2003: Saturday, June 15, 12:30-1:30 p.m.

Consolidated Committees (Curriculum Materials, Distinguished Librarian Award, Gerontology, Government Policy, Instruction for Educators, Membership and Orientation, Publications and Communications, Reference Sources and Services): Saturday, June 15, 9:30 a.m. $-12: 30$ p.m.
Curriculum Materials Centers Standards/Guidelines: Public Hearing Sunday, June 16, 1:00-2:00 p.m.; Committee Meeting, Sunday, June 16, 2:004:00 p.m.

Historical Textbook and Curriculum Collections Directory (Ad Hoc Committee): Sunday, June 16, 8:00-9:30 a.m.

Membership: Saturday, June 15, 11:30 a.m.-12:30 p.m.

Member Social: Saturday, June 15, 4:30-6:00 p.m.

New Leader Orientation: Sunday, June 16, 8:009:00 a.m.

Psychology/Psychiatry: Saturday, June 15, 8:3011:00 a.m.

Publications and Communications: Saturday, June 15, 8:00-9:00 a.m.

Social Work/Social Welfare: Friday, June 14, 4:30$6: 30$ p.m.

\section{Instruction Section}

Program: Sunday, June 16, 1:30-3:30 p.m. "Building Premier Learning Communities: Strategies for Successful Librarian Involvement."

Program (Co-sponsored by LES): Saturday, June 15, 2:00-4:00 p.m. "Teaching Literary Research: Challenges in a Changing Environment."

Dinner: Friday, June 14, 6:00-9:00 p.m. Gordon Biersch Brewery Restaurant, $\$ 34$. Contact: Nancy Reinhold at libngr@emory.edu.

LIRT/IS 25th Anniversary Reception: Sunday, June 16, 12:30-1:30 p.m.

Executive: Saturday, June 15, 8:00-9:00 a.m.; Tuesday, June 18, 8:30 a.m.-12:30 p.m.

Advisory Council: Saturday, June 15, 9:30-11:00 a.m.; Monday, June 17, 2:00-4:00 p.m.

Communication: Saturday, June 15, 2:004:00 p.m.

Conference Program Planning-Atlanta, 2002: Saturday, June 15, 2:00-4:00 p.m.

Conference Program Planning-Toronto, 2003: Meeting: Sunday, June 16, 8:30-10:30 a.m.

Education: Saturday, June 15, 2:00-4:00 p.m.

Emerging Technologies in Instruction: Saturday, June 15, 2:00-4:00 p.m.

Immersion Alumni: Sunday, June 16, 9:30-11:00 a.m. Instruction for Diverse Populations Committee: Saturday, June 15, 2:00-4:00 p.m.

Management of Instruction Services: Saturday, June 15, 2:00-4:00 p.m.

Membership: Saturday, June 15, 2:00-4:00 p.m.

New Leadership Orientation: Saturday, June 15, 11:30 a.m.-12:30 p.m.

Nominating 2003: Saturday, June 15, 2:00-4:00 p.m. (closed) 
Planning: Saturday, June 15, 2:00-4:00 p.m.

Policy: Committee Meeting, Saturday, June 15, 2:004:00 p.m. Public Hearing on "Guidelines for Instruction Programs," Saturday, June 15, 4:305:30 p.m

Preconference Program Planning, Atlanta, 2002: Saturday, June 15, 2:00-4:00 p.m.

Preconference Program Planning-Toronto, 2003: Saturday, June 15, 2:00-4:00 p.m.

Research and Scholarship: Saturday, June 15, 2:00-4:00 p.m.

Teaching Methods: Saturday, June 15, 2:00-4:00 p.m. Brainstorming: Saturday, June 15, 4:30-5:30 p.m.

\section{Law and Political Science Section}

Program: Saturday, June 15, 2:00-4:00 p.m. "Librarians in the Big Leagues: Are You Ready for the Teaching Academy?"

Conference Program Planning-Atlanta, 2002: Saturday, June 15, 10:30 a.m.-12:00 p.m.

General Membership: Sunday, June 16, 2:00-4:00 p.m.

Marta Lange/CQ Award Luncheon: Saturday, June 15, 11:30 a.m.-12:30 p.m.; Committee: Sunday, June $16,4: 30-5: 30$ p.m. (closed)

\section{Literatures in English}

Program (Co-sponsored by IS): Saturday, June 15, 2:00-4:00 p.m. "Teaching Literary Research: Challenges in a Changing Environment."

Executive: Saturday, June 15, 9:30-11:00 a.m.; Monday, June 17, 11:30 a.m.-12:30 p.m.

All Committees: Monday, June 17, 8:30-11:00 a.m.

General Membership: Sunday, June 16, 2:004:00 p.m

Literary Reference Discussion Group: Sunday, June 16, 9:30-11:00 a.m.

19th-Century Materials Discussion Group: Sunday, June 16, 11:30 a.m.-12:30 p.m.

Nominating: Monday, June 17, 9:30-11:00 a.m (closed)

Reception: Saturday, June 15, 4:15-9:00 p.m.

\section{Rare Books and Manuscripts Section}

Program (Co-sponsored by ARTS): Saturday, June 15, 1:30-5:30 p.m. "Artist's Books: Creating, Publishing, and Collecting."
Program (Co-sponsored by ARTS): Sunday, June 16, 1:30-5:30 p.m. "The Emergence of Digital Scholarship: New Models for Librarians, Archivists, and Humanists."

Executive Board: Monday, June 17, 8:30 a.m-12:30 p.m.

Bibliographic Standards: Saturday, June 15, 8:30 a.m.-12:30 p.m; Sunday, June 16, 8:30-11:00 a.m

Bibliographic Standards-Thesaurus Subcommittee: Friday, June 14, 2:00-5:30 p.m.

Budget and Development: Saturday, June 15, 2:00-4:00 p.m.

Committee to Revise Standards for Ethical Conduct (Ad Hoc): Sunday, June 16, 11:30 a.m12:30 p.m.

Conference Development: Sunday, June 16, 8:3011:00 a.m

Conference Program Planning-Atlanta, 2002: Saturday, June 15, 11:30 a.m.-12:30 p.m.

Conference Program Planning-Toronto, 2003: Sunday, June 16, 9:30-11:00 a.m.

Curators and Conservators Discussion Group: Sunday, June 16, 8:30-11:00 a.m.

Effects of 9/11 on Special Collections Discussion: Saturday, June 15, 11:30 a.m.-12:30 p.m

Exhibition Catalogue Awards: Saturday, June 15, 8:30 a.m.-12:30 p.m. (closed)

Information Exchange: Sunday, June 16, 4:30-5:30 p.m.

Manuscripts and Other Formats Discussion Group: Saturday, June 15, 9:30-11:30 a.m.

MARC for Special Collections Discussion Group: Sunday, June 16, 11:30 a.m.-12:30 p.m.

Membership and Professional Development: Saturday, June 15, 8:30-11:00 a.m.

Nominating: Saturday, June 15, 11:30 a.m.-12:30 p.m. (closed)

Preconference Program Planning-Atlanta, 2002 Sunday, June 16, 11:30 a.m.-12:30 p.m.

Preconference Program Planning-Toronto, 2003: Saturday, June 15, 8:30-11:00 a.m.

Preconference Program Planning-2004: Saturday, June 15, 11:30 a.m.-12:30 p.m.

Publications: Saturday, June 15, 2:00-4:00 p.m

Public Services Discussion Group: Sunday, June 16, 9:30-11:00 a.m.

Security: Saturday, June 15, 8:30-11:00 a.m. Seminars: Saturday, June 15, 2:00-4:00 p.m.

\section{Science and Technology Section}

Program: Monday, June 17, 8:30-10:30 a.m. "Old, New, Borrowed, and Blue: Science and Technology Intellectual Property Issues in the Digital Age"; Poster Session: 10:30-11:30 a.m 


\section{Preconferences}

From Expectations to Results: Friday, June 14, 8:00 a.m. $-4: 30$ p.m. (closed)

Legislative Advocacy Workshop: Friday, June 14, 12:00-4:30 p.m.

IS Preconference-Instruction for First-Year Undergraduates: Friday, June 14, 8:00 a.m. $-5: 30$ p.m.

RBMS Preconference--New Occasions, New Duties: Changing Roles and Expectations in Special Collections: Tuesday, June 11Friday, June 14

College Science Librarians Discussion Group: Saturday, June 15, 9:30-11:00 a.m.

Comparison of Science and Technology Libraries: Saturday, June 15, 8:00-11:00 a.m.

Conference Program Planning-Atlanta 2002: Saturday, June 15, 9:30-11:00 a.m.

Conference Program Planning-Toronto, 2003: Saturday, June 15, 8:00 a.m.-12:30 p.m.

Continuing Education: Sunday, June 16, 9:3011:00 a.m.

Council: Friday, June 14, 8:00-10:00 p.m.; Monday, June 17, 8:00-10:00 p.m.

Discussion Group Chairs: Saturday, June 15, 11:30 a.m. $-12: 30$ p.m

Forum for Science and Technology Library Research: Sunday, June 17, 2:00-4:00 p.m

General Discussion Group (with RUSA/BRASS): Sunday, June 16, 9:30-10:00 a.m. "The Business of Science."

Government Information: Sunday, June 16, 8:0011:00 a.m

Heads of Science and Technology Libraries Discussion Group: Monday, June 17, 4:30-5:30 p.m.

Membership and Recruitment: Sunday, June 16 , 8:30-11:00 a.m.

New Member Orientation: Saturday, June 15, 9:30-11:00 a.m.

Nominating: Sunday, June 16, 11:30 a.m.-12:00 p.m. (closed)

Oberly Award: Saturday, June 15, 11:30 a.m.-12:30 p.m. (closed)

Organization and Planning: Saturday, June 15, 9:30-11:00 a.m

Publications: Saturday, June 15, 9:30-11:00 a.m. Publisher-Vendor Relations Discussion Group: Sunday, June 16, 9:30-11:00 a.m.

Research: Sunday, June 16, 2:00-4:00 p.m.
Science Databases Discussion Group: Sunday, June 16, 9:30-11:00 a.m.

Subject and Bibliographic Access: Saturday, June 15, 9:30-11:00 a.m.

\section{Slavic and East European Section}

Program: Sunday, June 16, 1:30-3:30 p.m. "What Do You Do When You Don't Have a Subject Specialist?"

Executive/Membership: Sunday, June 16, 4:005.30 p.m.

All Committee Meeting (Conference Planning 2003, Electronic Resources, Newsletter, Preservation): Saturday, June 15, 9:30 a.m.-12:30 p.m.

Automated Bibliographic Control: Sunday, June 16, 9:30 a.m.-12:30 p.m.

Continuing Education: Sunday, June 16, 9:30 a.m.12:30 p.m.

WESS/SEES Dinner Cruise: Sunday, June 16, 6:009:00 p.m., Stone Mountain Park

\section{University Libraries Section}

Program (Co-sponsored by LAMA): Saturday, June 15, 1:30-3:30 p.m. "Minding the Generation Gap: Learn How to Communicate and Work Together Across Generations." Reception: 3:305:30 p.m.

Executive: Saturday, June 15, 8:30 a.m.-12:30 p.m.; Monday, June 17, 8:30-11:00 a.m

Campus Administration and Leadership Discussion Group: Saturday, June 15, 11:30 a.m.-12:30 p.m.

Communications: Saturday, June 15, 11:30 a.m12:30 p.m

Conference Program Planning-Atlanta, 2002: Friday, June 14, 4:30-5:30 p.m.

Conference Program Planning-Toronto, 2003: Sunday, June 16, 9:30 a.m.-12:30 p.m.

Current Topics Planning: Sunday, June 16, 11:30 a.m. $-12: 30$ p.m.

Organization and Bylaws: Sunday, June 16, 9:3011:00 a.m.

Policy and Planning: Sunday, June 16, 9:00 a.m.5:30 p.m.

Public Service Directors of Large Research Libraries Discussion Group: Sunday, June 16, 2:00-4:00 p.m.

Standards and Guidelines Review: Saturday, June 15, 11:30 a.m.-12:30 p.m.; Monday, June 17, 2:00-4:00 p.m.

Urban Thirteen Libraries: Saturday, June 15, 4:305:30 p.m. 


\section{Western European Studies Section}

Program: Monday, June 17, 10:30 a.m.-12:00 p.m. "Mapping the Future of Historical Scholarship About Europe."

Executive: Tuesday, June 18, 9:30 a.m.-12:30 p.m.

Cataloging Issues Discussion Group: Saturday, June 15, 4:30-5:30 p.m.

Classical, Medieval, and Renaissance Discussion Group: Sunday, June 16, 4:30-5:30 p.m.

College and Medium-Sized Libraries Discussion Group: Saturday, June 15, 4:30-5:30 p.m.

Conference Program Planning-Toronto, 2003: Saturday, June 15, 11:30 a.m.-12:30 p.m

General Membership: Monday, June 17, 8:3010:00 a.m.

Germanists Discussion Group: Sunday, June 16 , 9:30-11:00 a.m.

International Conference Planning, Budget Subcommittee-2004: Sunday, June 16, 8:009:00 a.m.

International Conference Planning, Fundraising Subcommittee-2004: Monday, June 17, 4:305:30 p.m.

International Conference Planning, General2004: Monday, June 17, 8:00-10:00 p.m.

International Conference Planning, Local Arrangements-2004: Saturday, June 15, 4:305:30 p.m.

International Conference Planning, Program Committee-2004: Saturday, June 15, 8:009:00 a.m.
International Conference Planning, Publicity Committee-2004: Monday, June 17, 8:00-9:00 a.m.

Membership: Saturday, June 15, 9:30-11:00 a.m.

Nominating Committee: Saturday, June 15, 8:009:00 a.m

Publications: Sunday, June 16, 9:30-11:00 a.m.

Research and Planning: Sunday, June 16, 2:004:00 p.m.

Romance Languages Discussion Group: Saturday, June 15, 9:30-11:00 a.m.

Scandinavian Discussion Group: Monday, June 17, 4:30-5:30 p.m.

Social Sciences and History Discussion Group: Sunday, June 16, 11:30 a.m.-12:30 p.m.

Special Topics Discussion Group: Saturday, June 15, $11: 30$ a.m.-12:30 p.m

WESS/SEES Dinner Cruise: Sunday, June 16, 6:009:00 p.m., Stone Mountain Park.

\section{Women's Studies Section}

Program: Monday, June 17, 9:00 a.m.-12:00 p.m. "Women, Technology, and Libraries."

Executive: Sunday, June 16, 2:00-4:00 p.m.

All Committees: Sunday, June 16, 9:30-11:00 a.m.

Awards: Friday, June 14, 2:00-5:30 p.m. (closed)

General Membership Meeting: Sunday, June 16, 4:30-5:30 p.m.

GLBTRT, Pay Equity, Women Administrators Discussion Group: Saturday, June 15, 11:30 a.m.-12:30 p.m. "Introduction to Women's Issues in ALA."

\section{Future of Academic Librarianship}

The Focus on the Future Task Force would like to announce an Open Forum on the Future of Academic Librarianship. The Open Forum will be held on Sunday afternoon, from 2:00 to 4:00 p.m This important event will be a part of the data collection effort the task force is undertaking to create the first top ten issues list to be published in a fall issue of C\&RL News.

The Open Forum on Academic Library Futures will be key to the collection of member thoughts on the big questions facing librarianship. We will work in groups to identify the issues beyond daily work-life and consider the profession from a larger perspective. Issues related to the higher education environment, to the organization of libraries, to collection issues, or to information legislative issues, among others, might be discussed.

Among the questions to be considered are:

1. What are the key trends and developments that academic librarians need to pay attention to?

2. What issues are so serious that they might keep you awake at night?

3. How well prepared are we to address the big questions?

Please make plans to attend the Open Forum in Atlanta on Sunday afternoon. We need your help and your good ideas. 


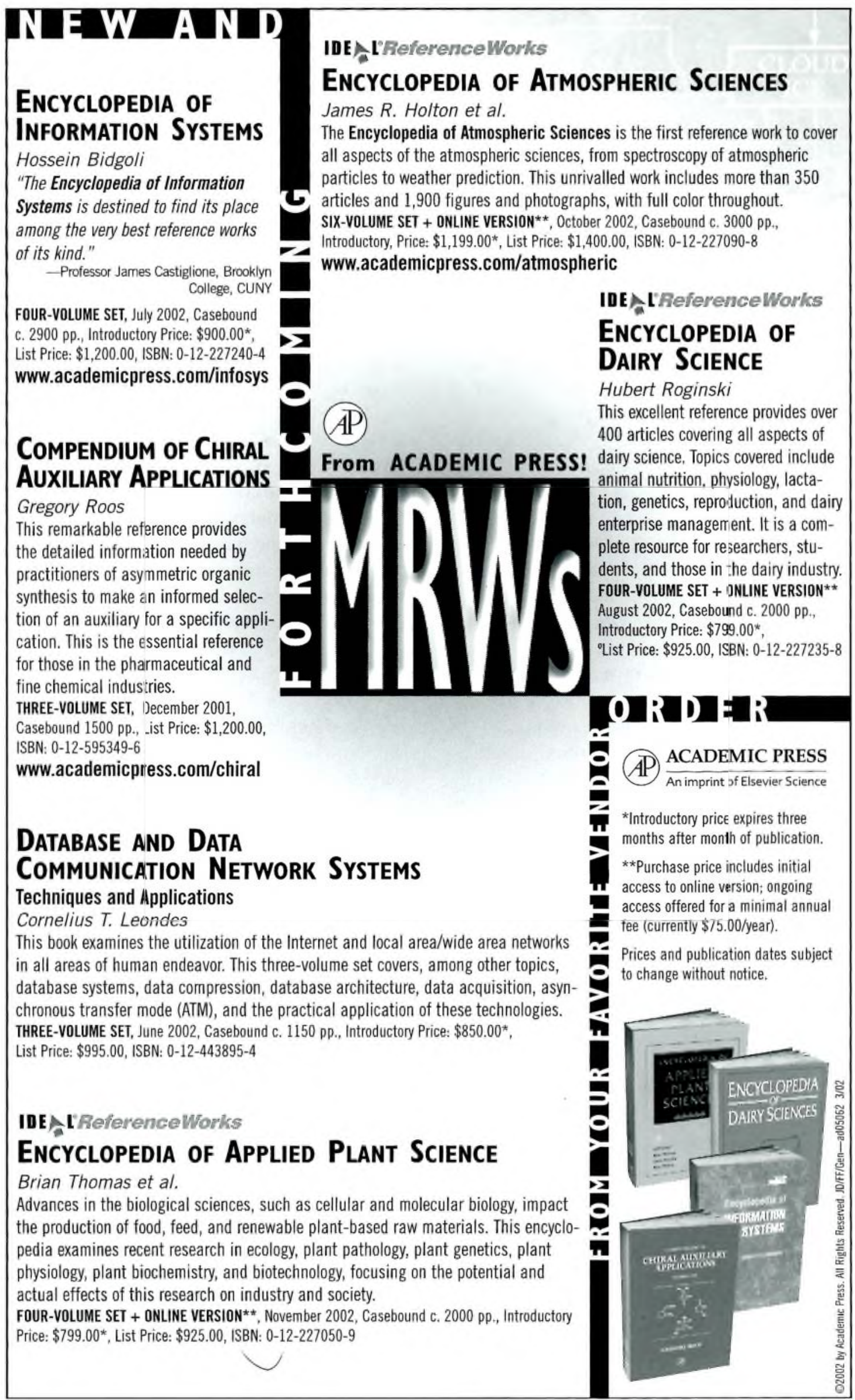

